\title{
The Morning After
}

\section{Assessing the Effect of Major Terrorism Events on Prosecution Strategies and Outcomes}

\author{
Kelly R. Damphousse \\ University of Oklahoma, Norman \\ Chris Shields \\ University of Arkansas, Fayetteville
}

\begin{abstract}
A major terrorism event has several important consequences for officials involved in the investigation and prosecution of terrorist activities. Such events are likely to bring increased scrutiny by both public policy officials and the media. The article uses data from the American Terrorism Study to compare the period before and after two of the most dramatic terrorist events on U.S. soil: the Oklahoma City bombing and the 9/11 attacks. The results suggest that whether intentional or not, major terrorism events result in the government's pursuing cases that are generally less serious and less complicated, and those cases are treated much more like "traditional" crimes by the prosecution. Following the aftermath of a major event, terrorist defendants are more likely to behave like traditional offenders and are less likely to be convicted as a result of a trial than are terrorists who are indicted before major events.
\end{abstract}

\section{Keywords: terrorism; sentencing; 9/11; Oklahoma City; prosecution}

$I^{n}$ n the history of terrorism in America, there are two watershed events to which all other events are compared. The Oklahoma City bombing was the first successful large-scale attack by extremists on U.S. soil-attacking what was perceived to be America's heartland. For many Americans, the attack highlighted a little known threat: the modern militia movement that had gained a foothold on our soil. The attacks of 9/11, on the other hand, highlighted the growing threat to the American way of life from outside the country. The deaths of nearly 3,000 victims, the wars in Iraq and Afghanistan, and the dramatic changes to "everyday life" resulted in most Americans denoting 9/11 as the date when everything changed. These two events not only awakened Americans to the risks posed by international and domestic terrorism, they also focused tremendous attention on the agents who are charged with maintaining public safety-notably law enforcement and prosecutors. Terrorism events of this scale challenge each level of government, but it is the federal government, specifically the FBI and the Office of the U.S. Attorney General, that has the mandate to respond. Because of increased public scrutiny on effectively combating 
terrorism, and because of the adoption of new rules (e.g., Uniting and Strengthening America by Providing Appropriate Tools Required to Intercept and Obstruct Terrorism [USA PATRIOT] Act) in the wake of these events, we expect that officials working for the FBI and the Office of the U.S. Attorney General have changed the way they operate. The goal of this article is to assess the extent of these changes in the context of (a) the history of how terrorism has been prosecuted in the past 25 years and (b) the theoretical explanations that predict specific outcomes as a result of critical events such as these.

The fact is, terrorism cases are rare in the American criminal justice system. When they do occur, their unique qualities present judges and prosecutors with legal and extralegal issues that are not typically encountered in other cases. Terrorism cases are more difficult to prosecute than traditional cases, even for similarly situated defendants who are charged with the same offense (Smith, 1994; Smith \& Damphousse, 1998; Smith, Damphousse, Jackson, \& Sellers, 2002; Smith, Damphousse, Yang, \& Ginther, 2005). One unique quality of terrorism cases, for example, is the fact that persons identified as terrorists are far more likely to end up going to trial than traditional defendants (Shields, Smith, \& Damphousse, 2006; Smith \& Damphousse, 1996, 1998; Smith et al., 2002). In addition, the public sentiment and media coverage focused on the defendants, their motivation, and their victims can compound the difficulties of winning a conviction.

By their very nature, major terrorism incidents such as the Oklahoma City bombing and the September 11, 2001, attacks often result in intense national media attention that places the spotlight on prosecution strategies and case outcomes (Chermak, 2003a). This added media attention is exacerbated by the fact that a relatively high percentage of terrorism cases result in a trial, so there is much to report on. Following the 9/11 attacks, media attention on the prosecution of terrorism cases has been especially focused and critical (see, e.g., Long \& Merzler, 2005; O’Hagan, 2004).

Despite the media attention on terrorism cases, few research studies have assessed the effect that "major" cases have had on terrorism investigations and prosecutions. The need for more research is particularly salient when one considers the tremendous resources that are currently being devoted to fighting terrorism.

This article focuses on changes in terrorism prosecution strategies by the federal government from 1980 to 2002 in response to two major events: the Oklahoma City bombing and the 9/11 attacks. Our analyses allow us to assess the relationship between these major events (and the presumptive media attention that resulted from the attacks) and the types of strategies used by prosecutors following the event.

To accomplish this task, it is important to place our discussion in context. We do this by describing the historical background of prosecuting terrorism cases in the United States and then provide a brief description of the differences between terrorism cases and traditional cases. After a review of the pertinent literature, we establish a theoretical framework using structural contextual theory (Hagan, 1989) and the trickle-up perspective (the "hydraulic effect") (Walker, 2005) to test our research questions. 


\section{Background}

Terrorism cases can be among the most visible cases that a prosecutor will handle in his or her career. Some cases will capture national attention: the trials of Zacarias Moussaoui, ${ }^{1}$ John Lindh, ${ }^{2}$ and Timothy $\mathrm{McVeigh}^{3}$ are classic examples. The impact of such high-profile ("top-layer") cases on the public perception of the criminal justice system is well documented (Walker, 2005). Although media attention seems to have reached its zenith in the wake of the September 11th attacks, according to some experts, intense media attention began in earnest after the Oklahoma City bombing (Chermak, 2003b; Smith et al., 2005). Prior to 1995, the media (and, therefore, the public) did not focus much attention on terrorism cases because the government did not openly politicize them. With few exceptions, terrorism cases were systematically treated as common crimes and they slipped through the courts relatively unnoticed. Convictions and acquittals were simply absorbed into overall federal court statistics. The extended trial of Timothy McVeigh and his conspirators and the aftermath of 9/11 have resulted in increased pubic scrutiny on the outcome of terrorism cases. This enhanced attention has placed considerable pressure on U.S. attorneys, the federal district courts, and policy makers who have made the war on terrorism their political centerpiece.

\section{A Shift in Policy and the Development of Prosecution and Defense Strategies}

Until the 1980s, the United States avoided any practice that might result in terrorists' being viewed by the public as anything but common criminals. Responding to public consternation about the Watergate scandal, Attorney General Edward Levi implemented guidelines for the FBI that dramatically limited its authority to engage in domestic security investigations. It is these guidelines that determine how the FBI and federal prosecutors can investigate domestic terrorism threats and attacks. As a result of these new guidelines, domestic security investigations dropped from 20,000 per year in 1973 to fewer than 300 in 1976 (Smith et al., 2002). When an investigation did occur, terrorists were charged and prosecuted like common criminals (Smith, 1994; Smith \& Damphousse, 1998; Smith et al., 2002).

In the early 1980s, a policy shift occurred in the wake of several armored-car robberies perpetrated by leftist groups. Responding to congressional pressure, Attorney General William French Smith implemented new attorney general guidelines for terrorism investigations. In 1983, the Smith Guidelines provided new authority for the FBI to investigate domestic terrorism groups. ${ }^{4}$ After applying an official terrorism investigation to a case, the FBI could investigate groups for longer periods of time than possible under a "general crimes" investigation. The guidelines also gave the FBI expanded authority to investigate international terrorists. The results of these new guidelines were rather dramatic as the FBI began to investigate and indict a 
growing number of left-wing and right-wing terrorists who were active in the early 1980s. The extreme left seems never to have recovered from these efforts. It is in this new era of increasingly political prosecution of terrorist groups that the Oklahoma City bombing occurred (note also that the bombing took place only 2 years after the failed attempt to blow up the World Trade Center and the trials surrounding the conspiracy to blow up the Holland Tunnel and other landmarks).

\section{Prosecution Strategies}

Changes in how the FBI was allowed to investigate domestic security offenses brought about a change in the methods used by federal U.S. attorneys to prosecute terrorists. Until the 1980s, prosecutors followed the same philosophy that investigators used, treating terrorists like common criminals. In the 1960s and 1970s, a few prosecutors experimented with politicizing terrorism cases, but the practice was generally avoided (Smith et al., 2002). After an analysis of political crime laws, Turk (1982) suggested that prosecutors used one of two methods, explicit politicality or exceptional vagueness, to prosecute terrorist defendants. Explicit politicality is characterized by the government's use of a terrorist label in trial documents and the portrayal of the defendant as a terrorist to the public through the news media. This strategy involves the extensive discussion of the defendant's motives and the use of charges that include an element of conspiracy alleging that the defendant has engaged in some type of politically motivated behavior. The most extreme example of this type of charge would be seditious conspiracy or treason.

When the exceptional vagueness strategy is employed, the government avoids describing the defendant as a terrorist. Instead, the defendant is depicted as a traditional criminal. According to Smith and Orvis (1993), this strategy frequently leads to the use of presumed or strict liability statutes where the act is presumed to be prima facie evidence of intent. For example, these charges might include possession of firearms or explosives. The key with this strategy is that by avoiding the issue of intent, prosecutors sidestep any discussion of the defendant's motive, thereby reducing the possibility that a juror might identify with the defendant's cause.

Subsequent research by Smith and colleagues (2002) expanded Turk's typology to include a third prosecutorial strategy. After analyzing the challenges faced in the prosecution of earlier terrorism cases, they suggested that government prosecutors sometimes use a middle-ground approach, which they coined "subtle innuendo." In this strategy the government charges a defendant either under a presumed liability statute or with some "traditional" crime where motive is not an issue. At trial, the prosecutor then drops a series of subtle, and not so subtle, hints that the defendant is part of a terrorist group.

Analyzing terrorism cases from 1990 to 2002, Smith et al. $(2002,2005)$ found that when the government brings explicit attention to a terrorist's motive, the case is more likely to proceed to trial than in those cases where a more traditional strategy 
is used. In addition, explicitly politicizing cases involving domestic terrorists did not yield good results in the early 1990s, although juries were willing to convict international terrorists under this strategy.

\section{Defense Strategies}

The government's foray into politicizing cases has led defense attorneys to develop a number of counterstrategies. According to Smith and Damphousse (1998), for example, defense attorneys have had success challenging politicized trials using due process claims. The most successful strategy, however, involved defense attorneys who tried to distance their clients from an alleged political ideology and/or group. A common technique used in disassociation involves filing motions to sever one defendant's trial from the rest of the group. Severance motions are most often used by lower-level group members who are afraid that standing trial with group leaders would result in a greater chance for conviction and harsher sentences.

Another disassociation method that is sometimes used in terrorism cases is an attempt by counsel to control what language can be used in a case. This may be an attempt to counter prosecutorial efforts to use subtle innuendo. To accomplish this, a defense attorney files a motion in limine asking the court to prohibit the prosecutor from making references to a group, an ideology, an event, or even the word terrorism. The legal argument for such a motion is grounded by the rules of criminal procedure. Judges may grant the motion if they feel that the probative value of the evidence that the prosecutor is attempting to introduce is outweighed by the prejudice that it may cause the defendant.

Many defendants in terrorism trials have claimed that they are the targets of political persecution. The rationale is to defeat the "motive" element alleged by the prosecutor by showing that instead of possessing a terrorist or political motive, the defendants' beliefs are benign while claiming that they are the targets of an overzealous witch hunt because they fall outside of the mainstream.

A number of other defense methods have been tried with mostly unremarkable results. Some defense attorneys have pursued a freedom fighter strategy, where the defendant claims that he or she was part of a legitimate effort to replace an existing, but corrupt, government. Another defense strategy attempted to portray the defendant's actions as acts of civil disobedience. Here, the defendants are portrayed not as criminals (or terrorists) but as citizens who were exercising freedom of expression. Defendants might also take a purely legal strategy by either (a) alleging that there were due process violations in the investigation and/or (b) attacking the constitutionality of the law. This defense method, anecdotally at least, has taken on new meaning in the post-USA PATRIOT Act court. Finally, some right-wing defendants have argued that the government lacks jurisdiction in the case. The goal appeared to be an attempt to compel juries to see the government as overstepping its original constitutional charter. 


\section{Challenges Associated With Motive and Labeling}

Highly politicized terrorism cases involve charges that sometimes force a prosecutor to prove the defendant's motivation. Typically avoided in American law, ${ }^{5}$ the focus on motive adds to the difficulty that prosecutors must overcome to convict terrorist defendants because motive is notoriously difficult to prove. Explicitly politicizing trials has an effect on case disposition in another way. Defendants who are labeled as terrorists enter guilty pleas at a dramatically lower rate than nonlabeled defendants indicted for the same lead offense; this is true even among terrorist defendants who are prosecuted using a more conventional strategy (Shields et al., 2006; Smith \& Damphousse, 1998; Smith et al., 2002).

Terrorist defendants who take their chances with a jury trial win acquittals at a higher rate (40\%) than other federal defendants (Smith et al., 2005). In contrast, the acquittal rate for federal criminal trials has varied from between 20\% in 1990 to $10 \%$ in 2004 (Ackman, 2004; Wright, 2005). The difficulty in proving motive may be one factor that explains why terrorist defendants enjoy a higher rate of acquittal than traditional defendants. High acquittal rates may also explain why the government shied away from explicitly politicizing domestic terrorism cases until after the Oklahoma City bombing. Despite higher acquittal rates, defendants who are labeled terrorists receive markedly longer prison sentences for the same offense upon conviction.

\section{New Legal Challenges}

Terrorism cases have been tried all over the country, but only a handful of federal prosecutors ever work a terrorism case, and those who do will probably not prosecute more than one terrorism case in a career. Unlike more traditional crimes in which prosecutorial strategies may be routine, assistant U.S. attorneys who handle terrorism cases can quickly find themselves in new territory. In addition to the defense strategies discussed above, a number of legal challenges have been raised in terrorism cases that prosecutors are likely to be unfamiliar with. For example, defendants implicated in acts of supporting or engaging in international terrorism have challenged information gathered under the Foreign Intelligence Surveillance Act (FISA; 1978), and after that law was broadened following September 11, 2001, those challenges appear to be occurring with more frequency. ${ }^{6}$

For example, the Sami Omar Al-Hussayen case ${ }^{7}$ involved numerous challenges to evidence gathered under FISA. The Zacarias Moussaoui case likewise tested the limits of the Classified Information Procedures Act (CIPA; 1988). Unlike any case that preceded it, much of the Moussaoui trial was held behind closed doors, and a significant portion of government's evidence remained sealed. In the Moussaoui case, Judge Brinkema was forced to strike a balance between the defendant's right to have the evidence used to determine his culpability presented in a public trial and the government's interest in protecting classified and sensitive information. 
CIPA was created in the early 1980 s to address the problem of "graymail," or the intentional release of classified government information by a defendant in a criminal trial. CIPA was designed to reconcile the defendant's right to obtain and introduce exculpatory material and the United States' duty to prevent the disclosure of sensitive information that could compromise national security. CIPA establishes pretrial, trial, and appellate procedures for federal criminal cases when there is a possibility that classified information might be disclosed. Under CIPA procedures, ideally, issues concerning the discoverability of classified information by the defendant or his or her counsel are resolved, sometimes ex parte and in camera, and the United States is made aware, prior to trial, through in camera hearings, of whether classified information will have to be disclosed in the criminal proceedings. The United States can then make an informed decision concerning the "costs" of going forward with the prosecution.

Section 3 of CIPA allows the government to apply for a protective order that applies to all materials furnished to the defendant or his or her counsel as a result of the government's discovery obligations. The order may also be used to prevent the defendant from disclosing classified information already in his or her possession. A protective order can also limit the defendant from seeing classified information himself or herself and allow only the defendant's attorney to view it after that attorney has passed a classification-certification process. For an example of CIPA issues raised in terrorism trials, see U.S. v. Rezaq (1988).

\section{Theoretical Framework}

Two theories inform our understanding of the effects of major terrorist events on how terrorist cases are handled. Structural contextual theory suggests that major events may create a situation where the full extent of the law can be applied to a situation through a process called couple tightening. Trickle-up (the hydraulic effect) theory suggests that policy shifts or social crises can create situations where relatively minor offenders are treated much more harshly than during "normal" times. The process is referred to as net widening.

\section{Structural Contextual Theory}

Structural contextual theory grew out of sentencing research and Hagan's assertion that our ability to predict sentence outcomes is substantially better for certain types of crimes (Hagan, 1989; Hagan, Nagel, \& Albonetti, 1980). According to this approach, disparity in sentence outcomes is lower for crimes in which policies have concentrated the criminal justice system's resources to combat crime. Hagan suggested that the American justice system is characterized by "loosely-coupled" components that work independently of, and sometimes compete with, one another. When 
political power is directed toward particular crime-linked goals, however, the system "tightens" through proactive techniques (Hagan, 1989).

Prior research has provided some support for structural contextual theory in terrorism cases: Nearly four times as much sentencing variance can be explained in terrorism cases compared to nonterrorism cases (Smith \& Damphousse, 1998). Using this theoretical approach then, terrorism is viewed as a serious problem by actors within the criminal justice system. Increased cooperation among those criminal justice actors results in lower levels of discretion when actors investigate, prosecute, and determine prison sentences after a conviction. The more serious the public perception is of a particular type of offense, the more evidence of "tightened coupling" we should find. According to Smith and Damphousse (1998), a proactive political environment may be a more important predictor of sentence length than crime severity.

We propose to test the theory in relationship to major terrorism events. After a major terrorism event such as the Oklahoma City bombing or the 9/11 attacks, we would expect the public to perceive higher levels of danger and to increase pressure on the government to take corrective action. This pressure, if we are correct, should result in a "coupling" of components in the criminal justice system, resulting in an increased number of terrorist indictments and indictees and an increase in the average sentence length following these events. In addition, the tightened coupling after a major attack should result in an increased level of explicit politicality by federal prosecutors who recognize a greater opportunity to convince juries of the potential danger of the defendants.

\section{Trickle-Up/Hydraulic Effect}

According to Walker (2005), "get tough" policy changes could also affect the way terrorism cases are prosecuted. Walker suggested that changes in policy that are meant to be directed toward serious offenses have a larger than anticipated effect on less serious offenses. A get-tough policy does not necessarily affect those crimes that are being targeted; rather, the government's new focus just casts a wider net. Raising nonserious events to a more serious level results in increased likelihood of being charged with an offense and decreased opportunities to plead guilty to a lesser charge. Because these policies reduce the chances for mitigation of the sentences, lower-level defendants tend to receive harsher punishment than we would expect to observe under normal circumstances.

This concept poses an interesting question in the light of terrorism cases. If Walker is correct about the hydraulic effect, we would expect to see an increase in the number people charged with low-severity offenses after a policy change. That is, after a serious terrorist attack, the net of the justice system would be widened to such an extent that individuals who would normally be ignored are now caught up in the justice system. In addition, we would also expect to see longer sentences given to lower-level crimes. Following Walker's reasoning, however, we would not expect such policy changes to have a dramatic effect on the more serious targeted crimes. Therefore, evidence of the hydraulic effect should come in the form of defendants' 
who are charged with lower-level crimes receiving longer sentences during the time immediately after a major terrorism event compared with the era before a major event. Evidence for this effect might also be measured by a higher frequency of lowlevel charges filed against a broader range of defendants after an event. We expect get-tough policies to result in a broader net being cast whereby individuals are charged with offenses that were not typically prosecuted before an event.

\section{Research Questions}

In this article, we use a unique data terrorism prosecution data set to examine the following research questions:

1. What was the short-term impact of two major terrorist events (the Oklahoma City Bombing and the September 11 attacks) on the number indictments filed? According to structural contextual theory, we expect that increased concern about terrorism as a result of these attacks would result in increased number of indictments and indictees in the 2 years following each attack.

2. What was the short-term impact of these two major terrorist events on the type of indictments filed? According to the hydraulic effect (net widening) theory, we expect to observe an increased number of relatively minor charges in the wake of these watershed events. We also expect to see less complicated cases (with fewer counts per indictment) in indictments following major events.

3. What was the short-term impact of the two major terrorist events on case outcomes or sentence severity? According to both structural contextual theory and hydraulic effect theory, we expect that sentence lengths would decrease following major events because prosecutors will be charging defendants with less severe crimes and with fewer counts.

4. What is the short-term effect of these two major terrorist events on the types of prosecution strategy that are used? According to structural contextual theory, we expect to see a greater amount of explicit politicality in the 2 years after a major terrorist event. According to the net widening perspective, we expect to observe greater use of conventional criminality after major events.

5. Finally, what is the short-term effect on defendant strategy during the prosecution? We expect that as terrorists are treated more like conventional terrorists, they will be more likely to behave like traditional federal offenders. Specifically, we expect that the prosecutorial strategy of conventional criminality will result in increased rates of convictions as a result of a guilty plea. In addition, this will also result in lower average sentence lengths postevent.

\section{Method}

\section{Data Source}

In the early 1980s, the FBI's Terrorist Research and Analytical Center began publishing an annual report that specified which crimes were investigated under the 
FBI's Counterterrorism Program. That report was the first official account of terrorist activity in the United States. In 1989, the FBI released the names of persons indicted as a result of these investigations for the period of 1980 through 1988 to the American Terrorism Study (ATS). The Department of Justice matched the list of terrorist indictees with federal court docket numbers assigned throughout the United States and Puerto Rico. The ATS began collecting demographic and sentencing data in each of the federal district courts where the trials occurred. Those data were then supplemented by information provided by the U.S. Sentencing Commission. ${ }^{8}$

Over the years, Smith and his associates continued to add data to the ATS whenever the FBI released a new set of names. The terrorists who are examined in this analysis were provided by the FBI in a series of releases to the ATS across more than a decade. The ATS includes the names of every person who has been indicted as the result of an official terrorism investigation from 1980 through 2004. In the absence of federal data on terrorism, the ATS stands alone as the best source of data to evaluate the government's response to terrorism during the past quarter century.

In the full data set used for this analysis, there are data on 615 indictees (564 individuals $^{9}$ ) from 1983 to 2003 . These indictments include 7,724 counts charged against "terrorists" in 207 indictments. About $90 \%$ of the indictees in the data set are male and about three quarters of the indictees are White. The analysis strategy was to assess the effect of two major events (the Oklahoma City bombing and the 9/11 attacks) on the prosecution of terrorism in the United States. As such, we selected cases in the ATS that occurred in from 1993 to 1997 (the 2 years before and after the Oklahoma City bombing) and from 1999 to 2003 (the 2 years before and after the 9/11 attacks). The Oklahoma City bombing coconspirators (McVeigh, Nichols, and Fortier) and Zacarias Moussaoui were removed from the data set so as to not confound the analysis (because we are examining the effect of their acts on subsequent trials). The resulting data set includes information on 123 indictments against 285 individual indictees.

\section{Variables}

In this article, we use unique variables that are housed in the ATS database: date of indictment, sentence length, prosecutorial strategy, number of counts per indictee, and trial conviction.

Based on the date of the indictment, all cases were assigned to one of four groups: pre- and post-Oklahoma City bombing and pre- and post-9/11 attacks. Only 1 indictment in 1995 occurred before the bombing; this indictment was coded as "prebombing," of course. There were 15 terrorist indictments between September 12 and December 31, 2001 , and they were listed as "post-9/11" events. Sentence length is a continuous variable measuring the total length of a defendant's prison sentence in months. Values range from zero (0), indicating no sentence or time served, to 480 months. ${ }^{10}$

Prosecution strategy is coded using three values. Explicit politicality was coded in each case where the government made a reference to a defendant's affiliation with 
a terrorist group. In these cases, the defendant was typically charged with some crime involving a form of conspiracy resulting in the prosecution's focusing, to at least some degree, on the defendant's motive. For the category exceptional vagueness, we used the label conventional criminality. Cases were coded as being handled as conventional offenses in those cases where the defendant was charged with a traditional crime and/or a presumed liability statute. Cases were coded using this value only when the government made no references to the defendant's possible terrorism ties in the record. Subtle innuendo was used to code the remaining cases. Typically, these cases involved charging the defendant with more traditional offenses that did not directly implicate the defendant's motive. These cases differ from conventional criminality in that the government, either in a document or in open court, made some reference to a terrorist group or terrorist act. The hints were subtle in that prosecutors never directly referred to the defendant a terrorist. On occasion, references were made during the sentencing phase of the case.

The prosecutorial strategies for each case were coded by having the data collection specialists who reviewed the case file present a summary of case to a panel of judges (including the ATS principal investigator and the ATS staff attorney). After the vetting procedure, the research team decided on a final determination of the "dominant" prosecutorial strategy. All strategy determinations were made independent of any discussions about case outcomes except where prior knowledge of the case made this impossible.

As a more manifest measure of prosecutorial strategy, we also examined the number of counts per indictee before and after the events. This value is coded directly from the indictment.

Although the ATS data allows for an assessment of defense strategy by examining claims by the defendant that the case was a matter of political persecution or civil disobedience and claims that the defendant is a "freedom fighter" or that the government lacked jurisdiction in the case, we rely on a simpler measure of defendant strategy. For the purposes of this analysis, we focus on the defendant's decision to take the case to trial. As we discussed earlier, criminal trials in the federal system are extremely rare-only about $5 \%$ of federal convictions are the result of a trial. Although a terrorist may gain by the added publicity of a trial, there is also much to lose. In the aftermath of a major terrorism event, indicted terrorists may see this as a good time to "lay low." To assess changes in defense strategies related to the decision to go to trial, we created a new variable (trial conviction), such that convictions resulting from a trial are coded equal to 1 and convictions that result from a guilty plea are coded to 0 (all other cases are coded as system missing).

\section{Findings}

The working data set includes information on 123 indictments against 285 individual indictees. There were 45 individuals who were indicted in 16 indictments 
Table 1

Number of Indictees and Indictments Before and After Major Terrorist Events

\begin{tabular}{lccc}
\hline & $\begin{array}{c}\text { Number of } \\
\text { Indictments }\end{array}$ & $\begin{array}{c}\text { Number of } \\
\text { Indictees }\end{array}$ & $\begin{array}{c}\text { Ratio of Indictees } \\
\text { to Indictment }\end{array}$ \\
\hline Before Oklahoma City bombing & 16 & 45 & 2.81 \\
After Oklahoma City bombing & 27 & 82 & 3.04 \\
Before 9/11 & 15 & 53 & 3.53 \\
After 9/11 & 65 & 105 & 1.62 \\
Total & 123 & 285 & 2.32 \\
\hline
\end{tabular}

Table 2

Number of Defendants per Indictment Before and After Major Terrorist Events

\begin{tabular}{|c|c|c|c|c|c|c|c|}
\hline & \multicolumn{2}{|c|}{1 Defendant } & \multicolumn{2}{|c|}{$\begin{array}{c}2-3 \\
\text { Defendants }\end{array}$} & \multicolumn{2}{|c|}{$\begin{array}{l}4 \text { or More } \\
\text { Defendants }\end{array}$} & \multirow{2}{*}{$\frac{\text { Total }}{n}$} \\
\hline & $n$ & $\%$ & $n$ & $\%$ & $n$ & $\%$ & \\
\hline $\begin{array}{c}\text { Before Oklahoma } \\
\text { City bombing }\end{array}$ & 10 & 62.5 & 3 & 18.8 & 3 & 18.8 & 16 \\
\hline $\begin{array}{l}\text { After Oklahoma } \\
\text { City bombing }\end{array}$ & 11 & 40.7 & 10 & 37 & 6 & 22.2 & 27 \\
\hline Before $9 / 11$ & 10 & 66.7 & 3 & 20 & 2 & 13.3 & 15 \\
\hline After 9/11 & 52 & 80 & 7 & 10.8 & 6 & 9.2 & 65 \\
\hline
\end{tabular}

during the 2-year period before the Oklahoma City bombing (see Table 1). In the 2 years following the bombing, there were 82 indictees named in 27 indictments. In the 2 years preceding the $9 / 11$ attacks, there were 53 terrorism-related indictees, but in the 2 years that followed, that number doubled to 105 individuals who were indicted for terrorism-related acts. It is interesting that the number of indictments, however, varied much more dramatically. There were only 16 indictments leading up to $9 / 11$, but there were 65 indictments afterward, a greater-than-fourfold increase. Notice that the ratio of the number of indictees per indictment stayed basically the same before and after the Oklahoma City bombing (about 3 indictees per indictment), but this number decreased by about 54\% (from an average of 3.5 indictees per indictment to about 1.6). These findings suggest that both major events resulted in increased activity by the federal government (more indictments were issued and more people were indicted) but that the attacks of 9/11 had much more far-reaching effects. ${ }^{11}$ The data suggest that net widening occurred to a greater extent following 
9/11 as the government sought a wider range of charges against individuals and small groups compared to the era before $9 / 11$.

A closer analysis of these data is provided in Table 2, where we present the number of defendants per indictment for the four time periods of interest. The interesting finding presented here is that the FBI has traditionally defined terrorism as an act that involves more than one person (i.e., groups). The data in Table 2 suggest, however, that it was not uncommon for the federal government to indict individuals. Indeed, before the Oklahoma City bombing, almost two thirds of indictments involved single indictees, whereas only about one in five indictments had four or more indictees. As suggested by Table 2, the number of indictees per indictment increased after the bombing. The findings for the $9 / 11$ event are strikingly different. In the 2 years prior to $9 / 11$, about two thirds of the indictments involved a single indictee (back to the pre-Oklahoma City bombing level). After 9/11, the number of single indictee cases actually increases to about four cases in five. Clearly, the two events had largely different effects on the government prosecution strategy.

Of the 285 indictees in the database used for this analysis, 28 were not convicted or were awaiting trial, 5 were deported without trial, and sentencing data are missing for an additional 26 cases. Thus, we have data on 226 sentenced terrorists for the 2-year period just before and after the Oklahoma City $(N=103)$ and September 11 $(N=123)$ attacks. The average sentence length for these 226 convicted offenders is 103.8 months $(\mathrm{SD}=149.9)$.

Both structural contextual theory and the net-widening hypothesis suggest that after a major event, there will be more people indicted and that they will be indicted for less serious offenses. Anecdotal evidence suggests that after 9/11, the FBI and the federal government became much more proactive in the investigation of criminal cases related to fraud and immigration. Indeed, understanding the types of offenses that were charged post-9/11 is instructive. In the 2-year period following $9 / 11$, the federal government charged terrorists with several offenses that it had not used in the previous 2 years: counterfeiting and forgery, embezzlement and theft, extortion and threats, malicious mischief, obstruction of justice, passports and visas, perjury, violation of Racketeer Influenced and Corrupt Organizations (RICO) statutes, treason, sedition, subversive activities, drug abuse prevention and control, forfeitures, monetary transactions, social security fraud, aviation offenses, international emergency powers, mass transportation offenses, and bribery. Clearly, the effect of 9/11 and the fact that the attacks involved foreign nationals affected the types of offenses that were used to prosecute terrorists in the United States.

There were also some substantive changes in charge patterns following the Oklahoma City bombing. Several new offense categories that had not been used in previous years were used to prosecute terrorists: general crimes, firearms offenses, mail fraud, obstruction of justice, perjury, racketeering, robbery/burglary, stolen property, terrorism, and forfeitures. It is interesting that the federal government did not attempt to try anyone for acts of treason, sedition, or subversive activities in the 
Table 3

Average Sentence Lengths for Terrorists Before and After Major Terrorist Events

\begin{tabular}{lcccc}
\hline & $\begin{array}{c}\text { Number of } \\
\text { Indictees }\end{array}$ & $\begin{array}{c}\text { Number of } \\
\text { Convictions (\%) }\end{array}$ & $\begin{array}{c}\text { Average Sentence } \\
\text { Length in Months }\end{array}$ & Difference \\
\hline $\begin{array}{l}\text { Before Oklahoma } \\
\quad \text { City bombing }\end{array}$ & 45 & $40(88.9)$ & 234.4 & $142.5^{* * * *}$ \\
$\begin{array}{l}\text { After Oklahoma } \\
\quad \text { City bombing }\end{array}$ & 82 & $63(76.8)$ & 91.9 & \\
$\begin{array}{l}\text { Before 9/11 } \\
\text { After 9/11 }\end{array}$ & 53 & $37(69.8)$ & 98.0 & $43.8^{*}$ \\
Total & 105 & $86(81.9)$ & 54.2 & \\
\hline
\end{tabular}

${ }^{*} p<.05 . * * p<.01 . * * * p<.000$.

2 years following the Oklahoma City bombing. Indeed, the case against Timothy McVeigh (excluded from these analyses) may well have been the most likely event that could have resulted in a successful sedition case. Instead, he was charged with homicide, probably to be certain to get a conviction, given the federal government's early lack of success trying sedition cases.

In Table 3, we present data on the average sentence length of federally convicted terrorists just before and just after major terrorism events. The data reflect what we expect according to our theory. Specifically, the number of indictees increased dramatically (doubling) after each terror attack, but the average sentence length for convictions following each attack decreased as well. For the Oklahoma City bombing, the average sentence length for convictions in the 2-year period before the attack was 234 months. This value drops to an average sentence length of about 92 months in the 2-year period following the bombing (a significant difference of 142.5 months).

Notice also that the success rate for convictions declined following the Oklahoma City bombing. A similar pattern was observed for the 9/11 attacks as well. The average sentence length was 98 months before the $9 / 11$ attacks and dropped by almost $50 \%$ to about 54 months in the 2 years following 9/11 (a significant difference of about 44 months). The only difference between the Oklahoma City bombing and the 9/11 attacks is that the postattack conviction rate is higher after 9/11, whereas it is lower after the Oklahoma City bombing. These data suggest support for our hypothesis that prosecutors will expand their definition of terrorism after a major terrorism attack even at the expense of obtaining lower sentences upon conviction. What is not clear in the data is the extent to which the FBI is proactively "preventing" terrorist acts before they occur after a major terrorism incident (arresting a suspect before he or she engages in a serious offense). The data do not allow for a closer examination of this possibility.

Prosecutors who are interested in obtaining quick convictions, to preempt future terrorist attacks or to appear to be proactively engaged in counterterrorism, are likely 
Table 4

Average Number of Counts for Terrorists Before and After Major Terrorist Events

\begin{tabular}{lccc}
\hline & $\begin{array}{c}\text { Number of } \\
\text { Indictees }\end{array}$ & $\begin{array}{c}\text { Average Number } \\
\text { of Counts per Indictee }\end{array}$ & Difference \\
\hline $\begin{array}{l}\text { Before Oklahoma } \\
\quad \text { City bombing }\end{array}$ & 45 & 6.0 & $1.3^{*}$ \\
After Oklahoma & 82 & 4.7 & \\
$\quad$ City bombing & & & $15.5^{* *}$ \\
Before 9/11 & 53 & 22.8 & \\
After 9/11 & 105 & 7.3 & \\
Total & 285 & 103.8 & \\
\hline
\end{tabular}

$* p<.05 . * * p<.01 . * * * p<.000$.

to rely on a conventional criminality strategy and simplify their cases as much as possible. Thus, we expect to observe less complicated cases in the aftermath of major terrorism events. This is operationalized by examining the number of counts charged against an indictee. The rationale is that complicated cases mean a larger number of counts.

In Table 4, we observe the number of criminal counts listed in an indictment for each of the terrorist indictees before and after our two major terrorism events. Our hypothesis is supported by the data. The average number of counts per indictee before the Oklahoma City bombing was about 6 . In the 2-year period following the bombing, federal indictees were charged with an average of just fewer than 5 counts each (this different is significant). The difference is more dramatic for the 9/11 attacks, where the average number of counts per indictee dropped from almost 23 counts to just more than 7 counts (again, this difference is statistically significant). Clearly, prosecutors changed their habits at least for a short time after terrorism events.

Finally, we examine the extent to which prosecutors change their strategy regarding how the case is presented both to the grand jury and to the trial jury (through the indictment and via statements made during the trial session). According to structural contextual theory, we expect that prosecutors will feel both the freedom and the need to explicitly politicize cases following a major terrorism event. According to the netwidening hypothesis, however, we would expect that as the government brings more cases into the system, the need to explicitly politicize these cases is minimized (because these are "simple" criminal cases).

All but two cases $(N=121)$ in the data set were coded as exhibiting explicit politicality $(n=40)$, conventional criminality $(n=38)$, and subtle innuendo $(n=43)$. The results are presented in Table 5. It is interesting that we find support for the netwidening hypothesis and not for structural contextual theory. That is, we find that after major terrorism events, it appears that federal prosecutors are more likely to use 
Table 5

Prosecutorial Strategy in Terrorism Trials Before and After Major Terrorist Events

\begin{tabular}{|c|c|c|c|c|c|c|c|}
\hline & \multicolumn{2}{|c|}{$\begin{array}{l}\text { Conventional } \\
\text { Criminality }\end{array}$} & \multicolumn{2}{|c|}{$\begin{array}{c}\text { Subtle } \\
\text { Innuendo }\end{array}$} & \multicolumn{2}{|c|}{$\begin{array}{c}\text { Explicit } \\
\text { Politicality }\end{array}$} & \multirow{2}{*}{$\frac{\begin{array}{c}\text { Number of } \\
\text { Indictments }\end{array}}{n}$} \\
\hline & $n$ & $\%$ & $n$ & $\%$ & $n$ & $\%$ & \\
\hline $\begin{array}{l}\text { Before Oklahoma } \\
\text { City bombing }\end{array}$ & 0 & 0 & 5 & 33.3 & 10 & 66.7 & 15 \\
\hline $\begin{array}{r}\text { After Oklahoma } \\
\text { City bombing }\end{array}$ & 9 & 33.3 & 10 & 37.1 & 8 & 29.6 & 27 \\
\hline Total & 9 & 21.4 & 15 & 35.7 & 18 & 42.9 & 42 \\
\hline
\end{tabular}

Note: $\chi^{2}(2)=9.97, p<.006$.

\begin{tabular}{|c|c|c|c|c|c|c|c|}
\hline & \multicolumn{2}{|c|}{$\begin{array}{l}\text { Conventional } \\
\text { Criminality }\end{array}$} & \multicolumn{2}{|c|}{$\begin{array}{c}\text { Subtle } \\
\text { Innuendo }\end{array}$} & \multicolumn{2}{|c|}{$\begin{array}{c}\text { Explicit } \\
\text { Politicality }\end{array}$} & \multirow{2}{*}{$\begin{array}{l}\begin{array}{l}\text { Number of } \\
\text { Indictments }\end{array} \\
n\end{array}$} \\
\hline & $n$ & $\%$ & $n$ & $\%$ & $n$ & $\%$ & \\
\hline Before $9 / 11$ & 1 & 6.7 & 7 & 46.7 & 7 & 46.7 & 15 \\
\hline After 9/11 & 28 & 43.8 & 21 & 32.8 & 15 & 23.4 & 64 \\
\hline Total & 29 & 36.7 & 28 & 35.4 & 22 & 27.9 & 79 \\
\hline
\end{tabular}

Note: $\chi^{2}(2)=7.62, p<.023$.

the conventional criminality strategy and less likely to use explicit politicality. The possible reason for this may well be a practical matter. In the aftermath of a terrorism event, prosecutors and investigators might feel pressured to use the prosecution strategy that has worked best in the past. As we discussed earlier, federal prosecutors have often been unsuccessful in using explicit politicality in trials. Thus, one might reasonably expect that in times of stress and crisis, the justice system actors turn to the tried-and-true method of trying the cases as "pure" criminal events (leaving aside the question of motive).

Similarly, we would expect that terrorism cases that are treated as conventional criminality should result in an increased likelihood of case outcomes that are similar to nonterrorism cases. For example, the percentage of convictions that result from a guilty plea for nonterrorists in the federal system is greater than $95 \%$. Terrorists, on the other hand, are far more likely to be convicted at trial. We predict, therefore, that terrorists who are treated like nonterrorists (via conventional criminality) will be more like to be convicted as a result of a guilty plea than those terrorists whose cases are explicitly politicized. In our data, 218 individuals were convicted of an offense: $73(34 \%)$ were convicted as a result of a trial, and $145(66 \%)$ were convicted as a result of a guilty plea (presumably because of a plea bargain).

In Table 6, we present the percent of conviction by guilty plea and trial before and after major terrorism events. The results suggest that the Oklahoma City bombing 
Table 6

\section{Prosecutorial Strategy in Terrorism Trials Before and After Major Terrorist Events}

\begin{tabular}{|c|c|c|c|c|c|}
\hline & \multicolumn{2}{|c|}{$\begin{array}{c}\text { Conviction by } \\
\text { Guilty Plea }\end{array}$} & \multicolumn{2}{|c|}{$\begin{array}{c}\text { Conviction by } \\
\text { Trial }\end{array}$} & \multirow{2}{*}{$\begin{array}{c}\begin{array}{c}\text { Number of } \\
\text { Indictees }\end{array} \\
n\end{array}$} \\
\hline & $n$ & $\%$ & $n$ & $\%$ & \\
\hline $\begin{array}{l}\text { Before Oklahoma } \\
\text { City bombing }\end{array}$ & 16 & 40.0 & 24 & 60.0 & 40 \\
\hline $\begin{array}{r}\text { After Oklahoma } \\
\text { City bombing }\end{array}$ & 30 & 47.6 & 33 & 52.4 & 63 \\
\hline Total & 46 & 44.7 & 57 & 55.3 & 103 \\
\hline
\end{tabular}

Note: $\chi^{2}(1)=.575, p=.448$.

\begin{tabular}{|c|c|c|c|c|c|}
\hline & \multicolumn{2}{|c|}{$\begin{array}{l}\text { Conviction by } \\
\text { Guilty Plea }\end{array}$} & \multicolumn{2}{|c|}{$\begin{array}{c}\text { Conviction by } \\
\text { Trial }\end{array}$} & \multirow{2}{*}{$\begin{array}{c}\text { Number of } \\
\text { Indictees }\end{array}$} \\
\hline & $n$ & $\%$ & $n$ & $\%$ & \\
\hline Before $9 / 11$ & 26 & 76.5 & 8 & 23.5 & 34 \\
\hline After 9/11 & 73 & 90.1 & 8 & 9.9 & 81 \\
\hline Total & 99 & 86.1 & 16 & 13.9 & 115 \\
\hline
\end{tabular}

Note: $\chi^{2}(1)=3.73, p=.05$.

had no significant effect on the likelihood of a conviction by way of trial. About $60 \%$ of convictions in the 2-year period before the bombing were the result of a trial (compared to about $5 \%$ for nonterrorists in the federal system). That figure dropped to about $52 \%$ in the period after the bombing, but that difference is not statistically significant.

The findings are dramatically different when we examine the percentage of convictions via guilty plea before and after the 9/11 attacks. Notice that in the 2-year period just before the attacks, about three quarters of terrorism convictions were the result of a guilty plea (a figure much closer to the standard federal (nonterrorist) data. After 9/11, however, as prosecutors moved steadily toward using more of a conventional criminality strategy, we observe that more than $90 \%$ of convictions are the result of a guilty plea. Thus, it appears that our hypothesis is supported: Increased emphasis on conventional criminality will result in terrorists' behaving more like nonterrorists, resulting in increased levels of convictions as a result of guilty pleas (i.e., fewer trials).

\section{Discussion}

Our analysis suggests that major terrorism events not only affect the victims and the general public but also have important ramifications for how the justice system 
responds to (and defines) subsequent acts of potential terrorism. The findings also suggest that individuals who are charged with acts of terrorism after a major terrorist event behave differently than before the event. Specifically, prosecutors and investigators appear to increase the number of terrorism-related indictments for relatively less serious offenses in the 2-year period following a major terrorism event. In addition, prosecutors during post-9/11 were more likely to charge single offenders (although this was not true following the Oklahoma City bombing) for acts that resulted in relatively short sentences (compared to the time before the event). This is surprising given the expectation that the postevent environment might result in longer punishment. Future analyses will examine this finding while controlling for severity of the instant offense. Finally, after major terrorism events, prosecutors were more likely to charge indictees with fewer counts (suggesting less complicated cases) and they were more likely to use conventional criminality when describing the case to the court. As a result of these latter patterns, we believe we are also seeing a pattern of changing terrorist behavior. In previous studies (e.g., Smith \& Damphousse, 1998), we observed that a relatively low percentage of indictees were convicted as a result of a guilty plea. It is interesting that just when prosecutors begin to treat terrorists more like "traditional" offenders, terrorists seem to act more like traditional offenders by forgoing a criminal trial at a rate much more like the traditional federal offender.

Our analysis is partially limited, however, because we do not have all the data available yet for the 2 years post-9/11. This could mask some of the impact of the hydraulic effect post-USA PATRIOT Act and subsequent changes to the attorney general's guidelines for the FBI: Attorney General Ashcroft issued revised guidelines in 2002 that expanded the FBI's authority to open an official terrorism investigation. Even so, the 1983 Smith Guidelines should provide a temporal marker from which to test this effect. In addition, the Antiterrorism and Effective Death Penalty Act of 1996 (AEDPA), which followed in the wake of the Oklahoma City Bombing, should provide another marker. Although mostly procedural in impact, AEDPA was hailed as a get-tough-on-terrorism policy change that purported to make it easier for the courts to impose, and for correctional facilities to carry out, the death penalty in some capital crimes by limiting habeas corpus applications.

It is worth noting here the USA PATRIOT Act was adopted during a flurry of similar policy changes. For example, Executive Order 13224 was signed by President George W. Bush on September 23, 2001. It authorized the secretary of the treasury to designate organizations and individuals that the secretary believes are supporters of terrorism. Once these designations are made, the government is authorized to seize the assets of those organizations or individuals. More important, the Homeland Security Act (HSA) of 2002 created the Department of Homeland Security. The HSA is one of the most dramatic reorganizations of the government in 50 years. The HSA is a sweeping antiterrorism bill giving federal law enforcement agencies broad powers to monitor citizens. Both of these policy changes would arguably have a dramatic impact on the hydraulic effect by themselves, but coupled with the USA PATRIOT Act, they represent the most prolific change in terrorism policy in the 
nation's history. It is for this reason that we expect future analyses of post-9/11 cases to provide more clear-cut evidence of the hydraulic effect.

\section{Future Research}

After the passage of the USA PATRIOT Act, defense attorneys appear to be challenging the constitutionally of new antiterrorism legislation with much more frequency. Challenges to the sufficiency of CIPA and attacks on the permissibility of evidence obtained through the newest version of FISA have been filed with appeals courts. The outcome and full impact of these challenges needs to be addressed. At the time of publication, cases containing these data were still being collected. An analysis of these issues will follow when the data become available.

Another question that appeared in this study is the distinction between an acquittal or dismissal on all charges and an acquittal or dismissal of some charges. We noticed that in many cases a defendant may be convicted of or plead guilty to some charges and receive an acquittal on or dismissal of others. To fully understand the dynamic of prosecutorial and defense strategies, an assessment of which charges are being dismissed should be performed. Are the more serious charges being dismissed, and if so, is there a relationship between prosecution and defense strategies? Anecdotally, it appears that the political persecution defense strategy may be ineffective with regard to a complete acquittal, but it might be effective at winning an acquittal on charges that allege political motive. Future research should focus on the effect of this defense strategy (and others) within a case. Similarly, an evaluation of the types of charges filed against terrorist defendants over time may shed light on whether prosecutors have developed a hybrid of the three accepted prosecution strategies, a kitchen sink strategy.

It should be noted from the analysis conducted above that although the effects post- Oklahoma City bombing are not as pronounced as the those post-September 11, the pre-Oklahoma City bombing era follows the highly publicized first World Trade Center attack (February 1993) and trials. An analysis of the first World Trade Center attack should be conducted to determine the impact of this event and to see whether the political environment that followed this attack masked some of the impact of the Oklahoma City bombing.

\section{Conclusion}

Terrorism events, and the policy changes that follow, have several important consequences for justice officials involved in the investigation and prosecution of terrorist activities. Major events focus increased scrutiny from public policy officials and the media on actors within the federal criminal justice system. The desire by federal actors to appear proactive in light of this scrutiny results in changes to investigative and prosecutorial strategies, and those changes have several intended and unintended consequences. 
Using data from the ATS, the authors conducted a case study that compared the period before and after the two most dramatic terrorist events on U.S. soil: the Oklahoma City bombing and the 9/11 attacks. The results suggest that whether intentional or not, major terrorism events result in the prosecution of cases that are generally less serious, are less complicated, and are treated much more like "traditional" crimes by the state. At the same time, defendants who are indicted in the aftermath of a major terrorist event are much more likely to behave like traditional offenders: Whether they react differently because they are charged with less severe offenses from the onset or because of a conscious desire to avoid being seen as a terrorist in front of a retributive jury, terrorist defendants are substantially more likely to plead guilty after a major event than are terrorists who are indicted before such events.

\section{Notes}

1. U.S. v. Zacarias Moussaoui (01 CR 455), U.S. District Court, Eastern District of Virginia.

2. U.S. v. John Phillip Walker Lindh (02 CR 37), U.S. District Court, Eastern District of Virginia.

3. U.S. v. Timothy McVeigh (96 CR 68), U.S. District Court, District of Colorado.

4. Along with the Smith Guidelines, Congress was debating a number of antiterrorism measures at that time (Smith, 1984).

5. Sedition and treason are two exceptions, but those statutes are rarely used. As this piece was being written in October 2006, Adam Yahiye Gadahn was indicted on treason charges related to his connection with alQaeda. His indictment marks the first time since World War II that an American has been charged with treason.

6. Because the American Terrorism Study is still gathering cases from the post-9/11 era, this point is not quantifiable. On an anecdotal level, the authors have noted an increase in challenges to Foreign Intelligence Surveillance Act-derived evidence. This issue, along with any potential repercussions, will be explored in more depth as the data collection is complete.

7. U.S. v Sami Omar Al-Hussayen, 03-CR-0048, United States District Court for the District of Idaho.

8. After receiving the FBI list, data collection teams visited the federal courthouses and archive facilities to review the identified cases and copy documents. Data gleaned from those documents were then coded into approximately 80 variables and entered into the American Terrorism Study database.

9. Some individuals were indicted more than one time.

10. All sentences longer than 480 months ( 40 years) were recorded to 480 to remove outliers.

11. Although our analysis demonstrated statistically significant changes after both events, the smaller changes following the Oklahoma City bombing could be the result of the residual impact of the first World Trade Center bombing and trials.

\section{References}

Ackman, D. (2004). Quattrone fought the long odds, and lost. Forbes. Retrieved October 8, 2006, from http://www.forbes.com/business/2004/09/09/cx_da_0909topnews.html?partner=links

Antiterrorism and Effective Death Penalty Act of 1996, One Hundred Fourth Congress of the United States of America, § 735.

Chermak, S. (2003a). Marketing fear: Representing terrorism after September 11. Journal for Crime, Conflict, and the Media, 1(1), 5-22.

Chermak, S. (2003b). Searching for a demon: The media's construction of the militia movement. Boston: Northeastern University Press. 
Classified Information Procedures Act, 94 Stat. 2025, 18 U.S.C.A., as amended by P.L. 100-690, Title VII, $\S 7020(\mathrm{G}), 102$ Stat. 4396 (1988).

Exec. Order No. 13224, 66 C.F.R. 49,079 (2001).

Foreign Intelligence Surveillance Act, Pub. L. No. 95-511, 92 Stat. 1783, codified as amended at 50 U.S.C. $\S 1801-1811,1821-1829,1841-1846,1861-1862$ (1978).

Hagan, J. (1989). Why is there so little criminal justice theory? Neglected macro- and micro-level links between organization and power. Journal of Research in Crime and Delinquency, 26, 116-135.

Hagan, J., Nagel, I., \& Albonetti, C. (1980). The differential sentencing of white-collar offenders in ten federal district courts. American Sociological Review, 45, 802-820.

Homeland Security Act, Pub. L. No. 107-296, 116 Stat. 2135 (2002).

Long, P. \& Merzler, M. (2005, December 6). Jury clears former Florida professor of terrorism-related charge. Miami Herald. Retrieved October 8, 2006, from http://uniset.ca/terr/news/miamiher_alarianacquit.html

O'Hagan, M. (2004, November 22). A terrorism case that went awry. Seattle Times. Retrieved October 8 , 2006, from http://seattletimes.nwsource.com/html/localnews/2002097570_sami22m.html

Shields, C., Smith, B., \& Damphousse, K. (2006). Their day in court: Assessing guilty plea rates among terrorists. Contemporary Journal of Criminal Justice, 22(3), 261-276.

Smith, B. (1984). Antiterrorism legislation in the United States: Problems and implications. Terrorism: An International Journal, 7(2), 213-231.

Smith, B. (1994). Terrorism in America: Pipe bombs and pipe dreams. Albany: State University of New York Press.

Smith, B., \& Damphousse, K. (1996). Punishing political offenders: The effect of political motive on federal sentencing decision. Criminology, 34, 289-322.

Smith, B., \& Damphousse, K. (1998). Terrorism, politics, and punishment: A test of structural-contextual theory and the "liberation hypothesis." Criminology, 36(1), 67-92.

Smith, B., Damphousse, K., Jackson, F., \& Sellers, A. (2002). The prosecution and punishment of international terrorists in federal courts: 1980-1998. Criminology and Public Policy, 1(3), 311-338.

Smith, B., Damphousse, K., Yang, S., \& Ginther, C. (2005). Prosecuting politically motivated offenders: The impact of the "terrorist" label on criminal case outcomes. International Journal of Contemporary Sociology, 42(2), 210-216.

Smith, B., \& Orvis, G. (1993). America's response to terrorism: An empirical analysis of federal intervention strategies during the 1980s. Justice Quarterly, 10, 661-681.

Turk, A. (1982). Political criminality: The defiance and defense of authority. Newbury Park, CA: Sage. U.S. v. Rezaq, 134 F.2d 1121, 1142 (D.C. Cir. 1988).

Walker, S. (2005). Sense and nonsense about crime and drugs. Belmont, CA: Wadsworth.

Wright, R. F. (2005, Fall). Trial distortion and the end of innocence in federal criminal law. University of Pennsylvania Law Review. Available from http://ssrn.com/abstract=702901

Kelly R. Damphousse is an associate dean in the College of Arts and Sciences and an associate professor of sociology at the University of Oklahoma. His research interests include terrorism, deception detection, and the drugs-crime nexus. He has been an associate director of the American Terrorism Study since 1994. His research has been published in Criminology, Criminology and Public Policy, Deviant Behavior, Homicide Studies, Youth \& Society, Social Behavior and Personality, and others.

Chris Shields, JD, is an attorney currently serving as a research associate in the Center for Terrorism Research in Fulbright College in the Department of Sociology and Criminal Justice at the University of Arkansas. He is completing coursework toward a $\mathrm{PhD}$ in public policy and serving as data manager on the American Terrorism Study. 